in memoriam 


\section{Beatriz Sarlo}

\section{Susana Zanetti, in memoriam}

Beatriz Sarlo es profesora jubilada de Literatura Argentina en la Facultad de Filosofía y Letras de la Universidad de Buenos Aires. Dictó cursos en las universidades de Columbia, Berkeley, Maryland y Minnesota; Fellow del Wilson Center en Washington y "Simón Bolívar Professor of Latin American Studies" en la Universidad de Cambridge. Tiempo pasado. Cultura de la memoria y giro subjetivo (Siglo XXI, 2005), Escritos sobre literatura argentina (Siglo XXI, 2007), La ciudad vista. Mercancías y cultura urbana (2009), La audacia y el cálculo (2011), Viajes. De la Amazonia a las Malvinas (Seix Barral, 2014), son sus últimas publicaciones.

Documento accesible en línea desde la siguiente dirección: http://revistas.javeriana.edu.co Nota publicada originalmente en La Nación, Buenos Aires, 21 de agosto de 2013, con el título "Susana Zanetti: investigadora latinoamericanista".

doi:10.11144/Javeriana.CL18-36.inme 
Había NACido EN el oeste del Gran Buenos Aires en 1933 y murió el 20 de agosto de 2013 en esta ciudad. En 2002 publicó su libro más importante, $L a$ dorada garra de la lectura. Lectores y lectoras de novela en América Latina. Allí están las obsesiones que impulsaron su vocación crítica: Jorge Isaacs, Carpentier, José Emilio Pacheco, Armonía Somers. Dos años después apareció en Mérida, Venezuela, una compilación de artículos: Leer en América Latina, cuya vastedad temática es asombrosa.

La literatura latinoamericana fue su obsesión estética e ideológica. En la Universidad de Buenos Aires y en la de La Plata, en Alemania y en casi todas las grandes ciudades de este continente, Susana Zanetti continuó la obra comenzada, en la modernidad, por Ángel Rama y Emir Rodríguez Monegal: escribir sobre la autoconciencia literaria de América Latina.

No puedo evocarla en otros términos que no sean los personales. Durante los años de la última dictadura, el departamento de Corrientes y Uruguay donde ella vivía fue mi refugio. Dándome ese albergue, ella supo que corría riesgos. A su manera se los cobraba en moneda literaria. Todas las noches me adoctrinaba en la literatura americana del siglo XIX, descubría mi ignorancia completa sobre la literatura colonial, me leía a Sor Juana o al Inca Garcilaso, me exhortaba a aceptar la superioridad del modernismo. El amor exagera siempre, cuando tiene razón y cuando no la tiene: Susana Zanetti monologaba comparando a Onetti con Robbe-Grillet y encontraba al uruguayo más interesante; otras veces, quería establecer la superioridad de Sarmiento sobre Balzac. Reíamos y discutíamos.

Nunca olvidaré su forma de recitar a Darío o a Vallejo. Un recitado exigente, que encerraba el pedido de que se reconociera que ellos eran tan grandes como los grandes europeos. La conmovía la construcción imaginaria de una identidad, ese gran trabajo de símbolos e instituciones, que atravesaba América desde la Independencia. Será recordada por miles de estudiantes y decenas de discípulos, por una generosidad intelectual sin concesiones y sin competencias. 